\title{
Solar-powered flood early warning system with short message service (SMS) notifications
}

\author{
Nur Anis Athirah, N. H. Radzi, M. N. Abdullah, S. A. Jumaat, N. Z. Mohamad \\ Green and Sustainable Energy Focus Group (GSEnergy), Faculty of Electrical and Electronic Engineering, \\ Universiti Tun Hussein Onn Malaysia, Malaysia
}

\begin{tabular}{|c|c|}
\hline Article Info & ABSTRACT \\
\hline Article history: & Flood is one of the most common hazards in Malaysia. Flood effects can be \\
\hline Received Oct 3, 2019 & $\begin{array}{l}\text { local, or very large, affecting the neighborhood or community and entire } \\
\text { river basins. This flood develops slowly; sometimes over a period of days }\end{array}$ \\
\hline Revised Dec 6, 2019 & while sometimes develop quickly in just few minutes. With the real time \\
\hline Accepted Dec 20, 2019 & $\begin{array}{l}\text { flood information, it will allow public safety organizations and other } \\
\text { emergency managers to effectively plan their resource deployment within the }\end{array}$ \\
\hline Keywords: & $\begin{array}{l}\text { limited time of alert. Hence, this project aims to design the solar powered } \\
\text { flood alert warning system by using solar energy as the power supply. }\end{array}$ \\
\hline $\begin{array}{l}\text { Flood problem } \\
\text { GSM module } \\
\text { SMS } \\
\text { Solar energy }\end{array}$ & $\begin{array}{l}\text { This system will send message using GSM to the residents to notify them } \\
\text { about the flood occurred. In this project, three LEDs were used to indicate } \\
\text { the height of the water levels which are safe, alert and danger conditions. } \\
\text { Each of the height have different water level that indicates the level of safety } \\
\text { for each condition. }\end{array}$ \\
\hline
\end{tabular}

Copyright $\odot 2020$ Institute of Advanced Engineering and Science. All rights reserved.

\section{Corresponding Author:}

Nur Hanis Binti Mohammad Radzi,

Department of Electrical Engineering,

Faculty of Electrical and Electronic Engineering,

86400 Parit Raja, Batu Pahat, Johor.

Email: nurhanis@uthm.edu.my

\section{INTRODUCTION}

Nowadays, with the sudden climate change, geographical location and also unexpected natural phenomenon could lead to the problem that resulting in damages which is flooding. Flood is natural event or occurrence where a piece of land (or area) that is usually dry land, suddenly gets submerged under water [1]. Sometimes this flood can occur suddenly and recede quickly. Others take days or even months to build and discharge. The water carries along objects like houses, bridges, cars, furniture and even people when flood happen in an area where people live. It can wipe away farms, trees and many more heavy items. Improper management of drains can cause flood to happen at the housing area. During a flood happen, there is plenty of water, but it is mostly polluted and not safe to drink. If people drink the dirty water, they may suffer from diseases such as typhoid and cholera. This phenomenon can cause people and animals died in the flash floods. Water supply and electricity are disrupted and people struggle and suffer as a result. People can get ready to survive a flood by filling many containers with fresh and clean drinking water and storing other emergency supplies. Moreover, flooding brings a lot of diseases and infections including military fever, pneumonic plague, dermatopathia and dysentery [2]. Therefore, previous researchers have come out with the solution in order to predict the chances of the flood occurrence for helping community [3-8].

As we know, the area of Batu Pahat was hit by flash flood on 14 November $2017[9,10]$. Heavy rain lasts more than two hours causing the overflow of water from the drainage system adjacent to the residential area. The height of the water is about 0.3 meters from the road level [10]. A total of 23 people from 10 families in Lorong Budin at km 31.5 of Jalan Batu Pahat-Ayer Hitam had to be evacuated to a flood relief centre after their homes were inundated following a two-hour heavy downpour [10]. The families can be 
evacuated earlier if they can receive early notification. Hence, this research was focusing on to develop an early flood alerts via SMS notifications in order to detect the water level and give an early notification or warning to the community and society about the flood. This developed system also can help the risked family to prepare and evacuate earlier to a safer or higher place for saving life and important belongings. This system also was integrated with the solar system as the energy sources in order to promote the application of renewable energy due to the depletion of the conventional sources $[11,12]$. In addition, battery and solar charger controller also were used for backup power supply system.

\section{SYSTEM ARCHITECTURE}

This solar powered flood early warning system uses solar energy as the power supply. The solar panel will charge the battery during day time and during night time the battery will supply power to the system [13-17]. The solar charger controller will be used to monitor the charging percentage of the battery. The Proteus 8 Professional software is used to design and run the simulation. Arduino Uno board is used to act as interface between the software part and hardware part of the system as well as to control the water level [15]. Moreover, this system will send message using Global System for Mobile communication (GSM) to the residents to notify them about the flood occurred. In this project, three LEDs were used to indicate the height of the water level which are safe, alert and danger conditions. Each of the height have different water level that indicates the level of safety for each condition. When the water level reach at the certain height, the indicate LED lights up. For the green LED, this LED indicate the safety condition. In this condition, GSM does not need to send message to the resident because of the safety condition. Yellow LED indicates the alert level and give message to the residents to notify them about the height of the flood occurred. For the red LED, this LED indicates the danger level because of the maximum water level has reached and need to notify the resident about the warning of the flood.

\section{RESEARCH METHODOLOGY}

This project involves the following components: the solar panel, Arduino Uno, GSM module, water level sensor, mobile phone and LEDs. The block diagram below shows the process needed to complete the project. Based on Figure 1, it can be seen that the source of this system is using solar panel. When using the solar panel, the solar charger controller must also need to be used in order to ensure that the battery is not overcharge during the day and the power does not run backwards to the solar panels overnight and drains the batteries $[18,19]$. A drained battery will completely will lose some of its overall capacity and will decreases the efficiency of the solar charger controller [20]. There are three LEDs that involved in this project which are green, yellow and red. These LEDs will indicate the level of safety at certain height of water level [21]. Moreover, to detect the height of the water level, it is necessary to use the water level sensor [22]. This water level will measure the height of flood and displayed on the Liquid Crystal Display (LCD) screen [23]. Arduino Uno as a microcontroller will control the overall system for this project [24]. After received the information for the height of water level, the microcontroller will process the information and send to the GSM shield [25]. This GSM shield is used to send the information to the registered number phone of the residents about the level of safety when floods occur. The flowchart of the project was shown in Figure 2.

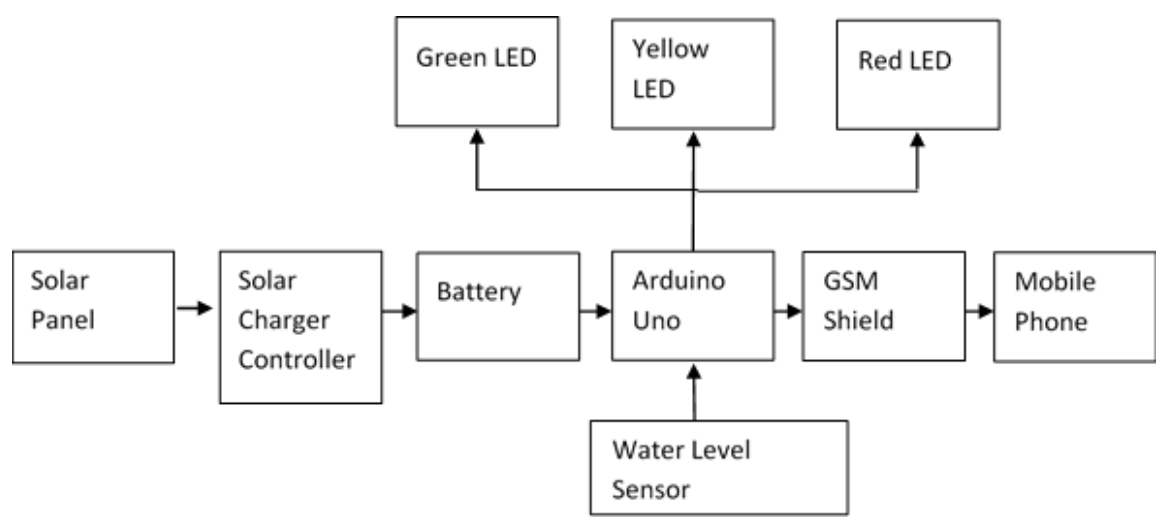

Figure 1. Block diagram of the project 


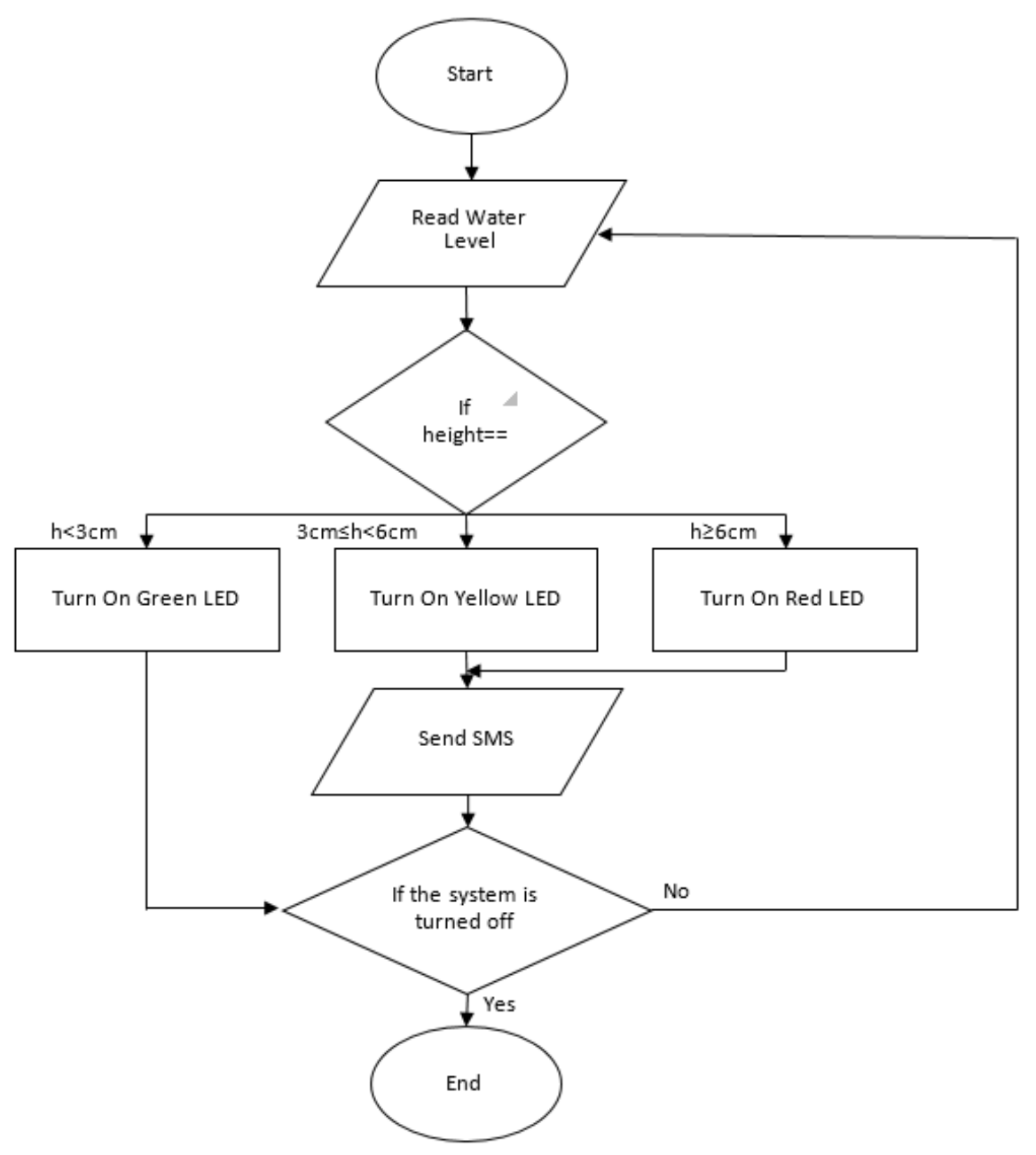

Figure 2. Flowchart of the project

\section{RESULT AND ANALYSIS}

This chapter provides the details about the hardware result. In this section, the design circuit and the overall project are presented.

\subsection{Flood Early Warning System Circuit}

This part explains the result for the hardware prototype configuration of the flood early warning system. Figure 3 shows the testing of system using solar panel $12 \mathrm{~V}$, battery $1.2 \mathrm{AH}$ and $12 \mathrm{~V}$ solar charger controller. The result of this solar testing, the Arduino Uno can be powered up and hence supplied electricity to the overall system.

The prototype was tested to observe the height of the water level when the flood occurred and the Arduino was used to control the overall system depending on the water level sensor that was dipped in the water as shown in Figure 4. When the sensor value of the water level sensor detects no water, the green LED not lights up and the LCD shows $0 \mathrm{~cm}$ for the height of the water level. In this condition, the condition remains safety because no flood occurred. When the sensor value of the water level sensor detects up to 600 , the green LED is lights up as shown in Figure 5. The LCD displayed the height of the water level up to $2.9 \mathrm{~cm}$. At this level, green LED still indicates the safety level to the residents.

When the sensor value increases up to 680, yellow LED lights up because of the water level has been increasing and this condition shows the alert level as shown in Figure 6. At this level, the height of water has been increasing to $5.9 \mathrm{~cm}$. In this condition, GSM sends the notifications to the residents about the alert level.

Lastly, for the danger condition when the sensor value of the water level sensor increasing more than 680, red LED lights up to indicate the danger level at this condition as shown in Figure 7. At this level, 
LCD displays the height of the water level reaches $6 \mathrm{~cm}$ and above. When the flood increasing up to this level, GSM sends notifications to the residents to inform them about the flood occurred. Figure 8 shows the output voltage when this system is connected with the solar charger controller and the solar panel.

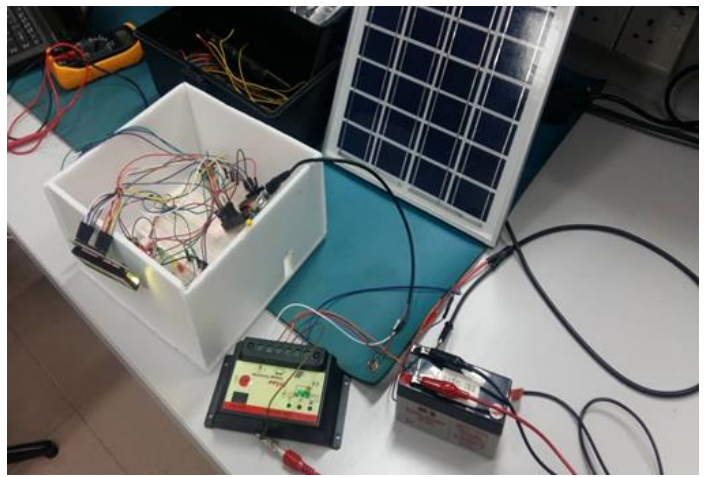

Figure 3. Testing of the solar system

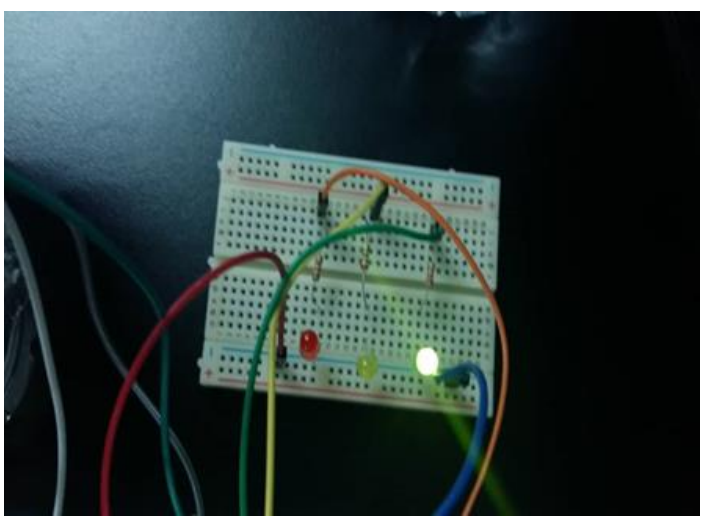

Figure 5. Green LED lights up

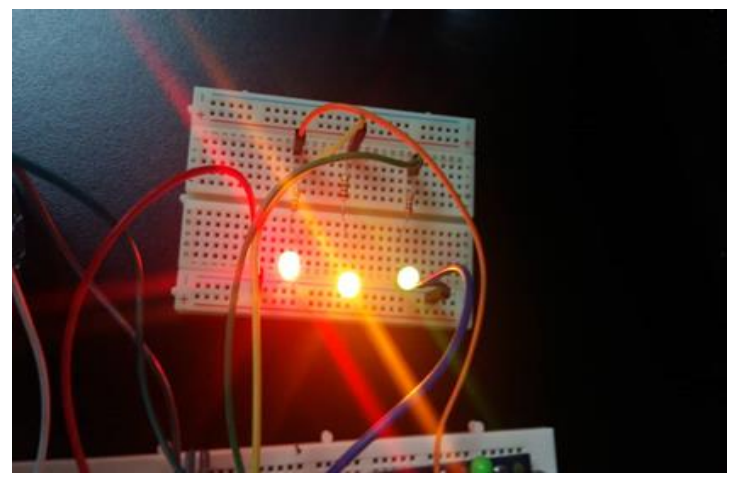

Figure 7. Red LED lights up

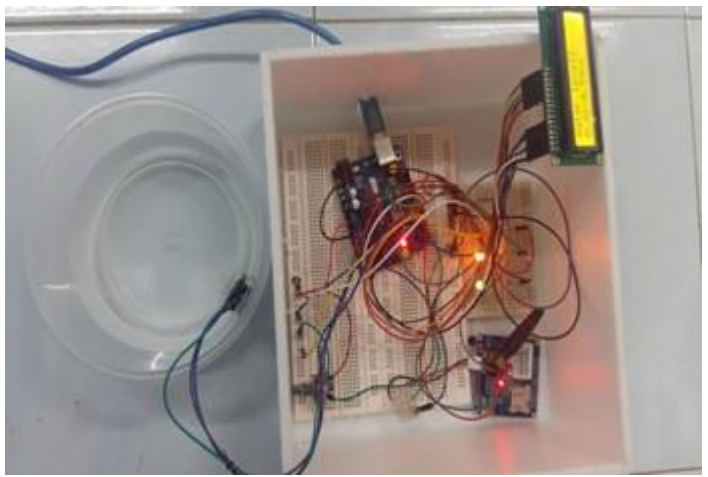

Figure 4. The flood early warning system circuit

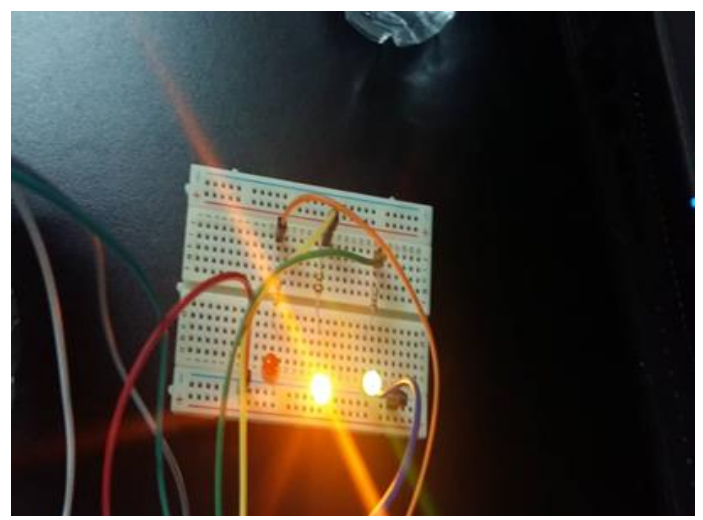

Figure 6. Yellow LED lights up

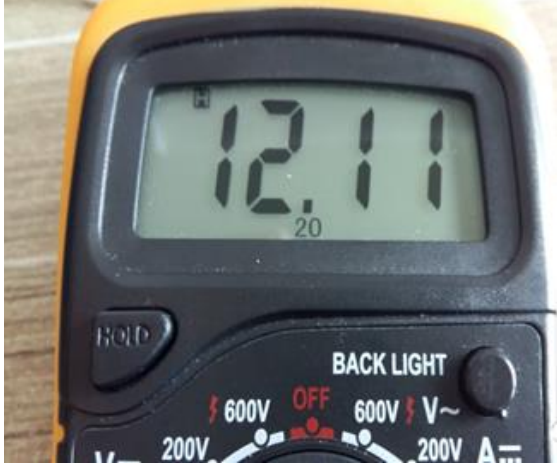

Figure 8. Output voltage for the system

\subsection{GSM Send Notifications to the Residents}

For the GSM parts, the function of GSM in this system is to send notifications to the residents about the condition level which consists of safety, alert and danger levels. However, for safety level, when the green LED lights up, GSM does not need to send notifications to the residents because of the safe condition. For the alert level when the yellow LED lights up, GSM sends notifications to the residents as shown in Figure 9. 
For the red LED, when the water level increases, LCD displays the height of the water level and GSM sends notifications to the residents about the danger level have occurred in that situation and they need to be under protection for that case. The notifications will be appeared via SMS as shown in Figure 10.

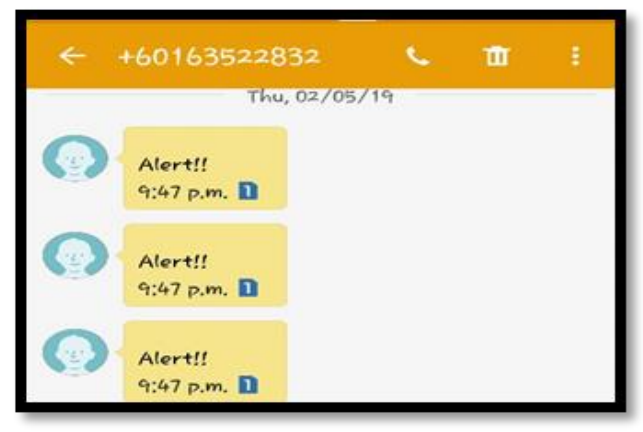

Figure 9. GSM send notifications when yellow LED light up

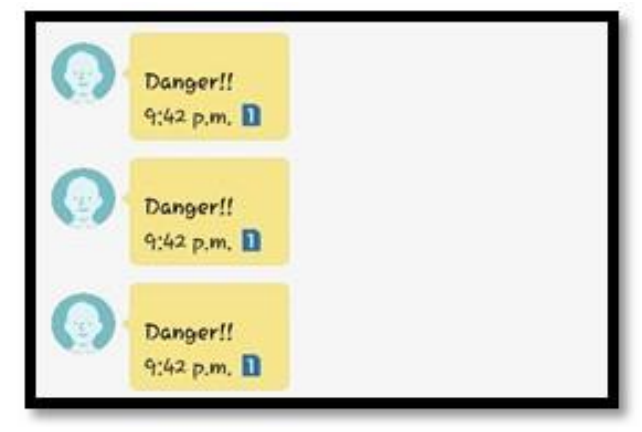

Figure 10. GSM sends notifications when red LED lights up

\section{CONCLUSION}

This paper has presented the development of the flood early warning system powered by solar panel with short message service (SMS) notifications. This system has successfully sent the message to the residents using GSM module to give notifications about the flood occurred. Solar energy has been used as the power source for this system. This system is more efficient as it integrated with the battery and solar charger controller. The battery was used as the backup power supply system when the solar panel is unavailable especially during night time. The solar charger controller monitored the percentage of battery capacity. The controller will cut off the charging process when the battery is fully charged. The implementation of the water level sensor had successfully applied in this system in order to measure the height of water level when flood occurs. This flood warning system used Arduino Uno to control the overall system. When the water level reaches alert or danger level where the yellow or red LEDs turn on, GSM will send message to the residents inform about the alert or danger condition. Thus, the residents can be well prepared and evacuated earlier for saving their life.

\section{ACKNOWLEDGEMENTS}

This work was supported by Universiti Tun Hussein Onn Malaysia through TIER 1 grant vot H156.

\section{REFERENCES}

[1] "Flood", [Online]. Available: https://en.wikipedia.org/wiki/Flood [Accessed on $2^{\text {nd }}$ October 2018]

[2] Effects of flooding, 2008 [Online]. Available: http://eschooltoday.com/natural-disasters/floods/effects-offlooding.html. [Accessed on $20^{\text {th }}$ September 2018].

[3] A. N. Yumang, C. C. Paglinawan, A. C. Paglinawan, G. O. Avendaño, Jose Angelo C. Esteves, Jan Ralley P. Pagaduan and Jesse Dave S. Selda., "Real-time Flood Water Level Monitoring System with SMS Notification," 2017IEEE 9th International Conference on Humanoid, Nanotechnology, Information Technology, Communication and Control, Environment and Management (HNICEM), Manila, 2017, pp. 1-3.

[4] W. A. H. W. M. Asmara and N. H. A. Aziz, "SMS Flood Alert System," 2011 IEEE Control and System Graduate Research Colloquium, Shah Alam, 2011, pp. 18-22.

[5] Agarwal, Arun., "Solar Powered Mobile Power Bank Systems," American Journal of Electrical and Electronic Engineering. 4. 148-151. 10.12691/ajeee-4-5-4, 2016.

[6] E. Kuantama, L. Setyawan and J. Darma, "Early Flood Alerts using Short Message Service (SMS)," 2012 International Conference on System Engineering and Technology (ICSET), Bandung, 2012, pp. 1-5.

[7] S. N. Sakib, T. Ane, N. Matin and M. S. Kaiser, "An Intelligent Flood Monitoring System for Bangladesh using Wireless Sensor Network," 2016 5th International Conference on Informatics, Electronics and Vision (ICIEV), Dhaka, 2016, pp. 979-984.

[8] J. G Natividad and J.M. Mendez, "Flood Monitoring and Early Warning System using Ultrasonic Sensor", IOP Confrence Series: Material Science and Engineering, 2018, pp. 325. 
[9] Banjir kilat di Batu Pahat, 14 November 2017 [Online]. Available: http://www.sinarharian.com.my/edisi/johor/banjir-kilat-landa-batu-pahat-1.757111. [Accessed on $24^{\text {th }}$ September 2018]

[10] Flash Floods hit Several Parts of Johor; Bad Weather predicted across 8 other States, 14 November 2017 [Online]. Available: https://www.nst.com.my/news/nation/2017/11/303153/flash-floods-hit-several-parts-johor-bad-weatherpredicted-across-8-other. [Accessed on 24th September 2018]

[11] S. A. Jumaat, O. W. Liang, M. N. Abdullah, N. H. Radzi, R. Hamdan and S. Salimin, "Modeling of 185W of Mono-crystalline Solar Panel using MATLAB/Simulink", International Journal of Power Electronics and Drive System (IJPEDS), vol. 10 (3), 2019, pp. 2005-2012.

[12] N. Oo, K. S. Lwin, and H. M. Tun, "A Charge Controller Design for Solar Power System," International Journal of Scientific \& Technology Research, vol.5, no. 06, pp.76-79, 2016.

[13] GreenMatch "Photovoltaic System," [Online]. Available: https://www.greenmatch.co.uk/solarenergy/photovoltaics/photovoltaic-system. [Accessed on $18^{\text {th }}$ October 2018]

[14] Live Science "How do Solar Panel Works?," [Online]. Available: https://www.livescience.com/41995-how-dosolar-panels-work.html. [Accessed on $20^{\text {th }}$ October 2018].

[15] Oday A. Ahmad, Hussain Sayed, Kanaan A. Jalal, Dhari Y. Mahmood, Waleed H. Habeeb, "Design and Implementation of An Indoor Solar Emulator based Low-Cost Autonomous Data Logger for PV System Monitoring”, International Journal of Power Electronics and Drive System (IJPEDS), vol. 10 (3), pp. 1645-1654, 2019.

[16] Energy Informative "Which Solar Panel Type is best? Mono, Polycrystalline or Thin Film?" [Online]. Available: http://energyinformative.org/best-solar-panel-monocrystalline-polycrystalline-thin-film/. [Accessed on 20th October 2018].

[17] Mybotic "Solar Cell 12V (10W)", $2010 . \quad$ [Online]. Available: https://www.mybotic.com.my/webshaper/store/viewProd.asp?pkProductItem=423. [Accessed on 25th October 2018].

[18] Northen Arizona Wind \& Sun "Solar Charger Controller Basics," [Online]. Available: https://www.solarelectric.com/learning-center/batteries-and-charging/solar-charge-controller-basics.html. [Accessed on 15th September 2018].

[19] AltE Store, "What is Solar Charger Controller," [Online]. Available: https://www.altestore.com/store/info/solarcharge-controller/. [Accessed on 20th September 2018.

[20] Mohammad Hadin A. Malek, Farahiyah Mustafa, Anis Maisarah Mohd Asry,"A Battery-Less Power Supply using Supercapacitor as Energy Storage Powered by Solar", International Journal of Power Electronics and Drive System (IJPEDS), vol. 10 (1), pp. 568-574, 2019.

[21] Peláez, E. A; Villegas, E. R, "LED power reduction trade-offs for ambulatory pulse oximetry," 29th Annual International Conference of the IEEE Engineering in Medicine and Biology Society, pp. 2296-9, 2007.

[22] PotientalLabs, "Water Level Sensor," [Online]. Available: https://potentiallabs.com/cart/buy-water-level-sensorliquid-water-droplet-depth-detection-online-hyderabad-indiathe. [Accessed on 15th September 2018].

[23] EngineersGarage, "16×2 LCD Datasheet," [Online]. Available: https://www.engineersgarage.com/electroniccomponents/16x2-lcd-module-datasheet. [Accessed on 12th September 2018].

[24] C. Hock-Chuan, "Getting Started with Arduino," 2015. [Online]. Available: http://www.ntu.edu.sg/home/ehchua/programming/arduino/Arduino.html. [Accessed on 26th October 2018].

[25] TechTarget "Definition for GSM," [Online]. https://searchmobilecomputing.techtarget.com/definition/GSM. [Accessed on 25th October 2018].

\section{BIOGRAPHIES OF AUTHORS}

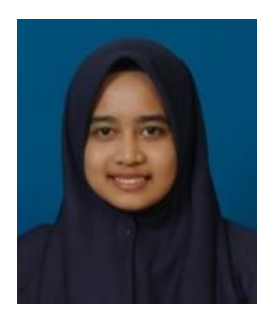

Nur Anis Athirah binti Juhaini was born in Malaysia, on July 25, 1996. She obtained Bachelor of Engineering in Electrical Engineering from Universiti Tun Hussein Onn Malaysia in 2019. Her specification in engineering is Electrical Power.

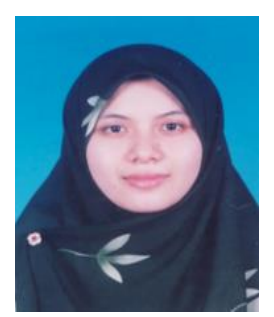

Nur Hanis Mohammad Radzi received her B.Eng. and M.Eng in Electrical Engineering (Power) from Universiti Teknologi Malaysia (UTM) in 2005 and 2009 respectively. She also received Ph.D from The University of Queensland, Brisbane, Australia in 2012. Currently, she is a senior lecturer in the Faculty of Electrical \& Electronic Engineering at Universiti Tun Hussein Onn Malaysia (UTHM). Her research interests include transmission pricing, power system economics, energy management and renewable energy. 

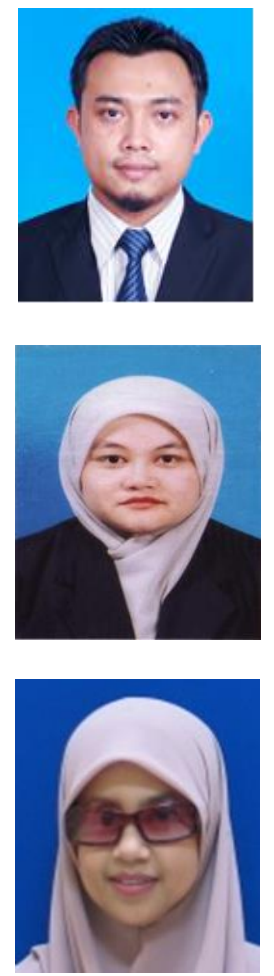

Mohd Noor Abdullah received his B.Eng. (Hons) in Electrical Engineering and M. Eng. in Electrical Engineering (Power System) from Universiti Teknologi Malaysia (UTM) in 2008 and 2010 respectively. He also received a Ph.D degree in Electrical Engineering from University of Malaya (UM) in 2014. He has been with Universiti Tun Hussein Onn Malaysia (UTHM) from 2008 to 2014 as a tutor. He is currently as a Lecturer in Department of Electrical Power Engineering, FKEE, UTHM. He also appointed as a head of Green and Sustainable Energy (GSEnergy) Focus Group in FKEE, UTHM. His research interests include electric power dispatch, distributed generation, renewable energy and meta-heuristic optimization techniques.

Siti Amely Jumaat was born in Johor, Malaysia on March 12, 1979. She graduated from the Institut Tun Hussein Onn (ITTHO-UTM) with honours degree in BSc. Electrical Eng. in 2001, MEng. (Power), UTM in 2003, and PhD in Electrical Eng at UiTM, Malaysia in 2015. Her research interests include power system and optimization techniques, FACTS devices, Artificial Intelligent techniques and renewable energy system. She is also a member of BEM, IEM, IEEE, and IEEE Power Engineering Society (PES) 2008.

Dr. Nor Zulaily Mohamad was born in Malaysia, on October 7, 1985. She obtained Bachelor of Engineering in Electrical Engineering from Universiti Teknologi Malaysia in 2007 and Ph.D in Electrical Engineering from Universiti Teknologi MARA (UiTM), Malaysia in 2017. Her research interest includes power system protection and power quality. She is currently a lecturer at Faculty of Electrical and Electronic Engineering in Universiti Tun Hussein Onn Malaysia (UTHM), Malaysia. 